\title{
Meeting Site Selection Criteria for Inbound and Domestic MICE: Thailand's Meeting Experts' Perspectives
}

\author{
Jaruwan Suwannasast ${ }^{1}$, Assistant Prof. Dr. Punthumadee Katawandee ${ }^{2}$, \\ Prof. Emeritus ${ }^{3}$, Dr. Achara Chandrachai ${ }^{4}$ \\ ${ }^{1}$ Technopreneurship \& Innovation Management, Graduate School, Chulalongkorn University, Thailand \\ ${ }^{2,3,4}$ Chulalongkorn Business School, Chulalongkorn University, Thailand
}

\section{Abstract}

There are many research studies on meeting destination competitiveness and site selection criteria, however, the empirical research of site selection attributes in developing countries like Thailand is still to be identified. This paper aims to investigate site selection attributes and present a conceptual framework to verify the importance of tangible attributes i.e. accessibilities, meeting facilities and additional conference opportunities. We also assess the intangible attributes such as destination information, local support, and site environments. All these factors will enhance Thailand's competitiveness as an International and domestic meeting destination.

The exploratory research method, combining in-depth interview and focus groups has been used with 12 local experts who specialize in meeting planning within Thailand. The literature review pre-determines site selection attributes included in meeting planner's decision-making processes to design a qualitative interview. Each interviewee is asked to rank the importance of 44 criteria's using a 1-7 scale (7 as highest importance and 1 as least importance. The findings will be used to compare similarities and differences with prior research. Consequently, the authors will develop a conceptual framework for meeting site selection criteria for inbound and domestic MICE in Thailand. According to the in-depth interviews, the accumulated 44 attributes are found to be aligned with previous literature with an average score of 5.2 out of 7.0. The 3 most important attributes are:1) Accommodation facilities 2) Accessibilities 3) Extra-conference opportunities. Further, focus group interviews suggest 17 new attributes, which falls into 1) Local support 2) Destination Information 3) Other criteria, respectively. The research aims for two objectives 1) Determine the importance of site selection attributes that will affect the meeting planner's decision-making process. 2) Compare the similarities and differences of site selection criteria with those found in previous researches using perception of local experts from corporate meeting planners in Thailand.

Keywords: Meeting industry, destination selection attributes, site selection criteria, destination competitiveness, destination marketing 


\section{BUSINESS, MANAGEMENT \& ECONOMICS}

\section{BERLIN, GERMANY}

\section{Introduction}

The Meeting industry as part of the tourism service sector plays an important role in two main dimensions: Economic stimulus from income distribution and creating jobs to the geographical location where the meetings take place. The Union of International Associations (UIA, 2018) reported that 10,786 meetings of International associations were held in 2017, 1.9\% lower than the number held in $2016(11,000)$ but $2.7 \%$ higher than the number recorded in $2012(10,498)$. In addition, International meetings grew 8\% per year on average between 2000 and 2014 (Jo, Park et al. 2019). In 2019, MICE, an acronym for the Meetings, Incentives, Conventions and Exhibitions tourism, in Thailand generated USD $\$ 1.67$ billion (550.2 billion Baht) and secured over 800,000 jobs, contributing $3.27 \%$ of the country's GDP (Thailand Convention \& Exhibition Bureau, 2020). Corporate and association meetings welcomed 639,094 International delegates to Thailand, generating 53.5 billion Thai Baht. This represented $56.9 \%$ of total MICE revenue.

The International Congress and Convention Association (ICCA) reported that Thailand is ranked $5^{\text {th }}$ in Asia with 171 International conferences. While the Union of International Association, or UIA 2016) reported that over $90 \%$ of International meetings in Thailand have been concentrated in Bangkok, Chaiang Mai, Pattaya and Khon Kaen with 263, 17, 8 and 5 meetings, respectively. Reasons for this are due to substandard facilities and inadequate level of service for both the organizers and service providers throughout the supply chain. The inadequate facilities include a lack of meeting venues, accommodation facilities, security, and accessibilities (MICE City Strategy and Development Program, Thailand Convention \& Exhibition Bureau, 2014).

This study aims to analyze the meeting site selection criteria for inbound and domestic MICE based on Thailand's meeting experts' perspectives. Previous researches have predominantly been based on the context of developed countries, where infrastructure and facilities are well connected. This finding helps develop a framework for domestic site selection criteria that would enable such organizations as Convention \& Visitor Bureau (CVB), Thailand convention \& exhibition bureau, Cities and Destination Management Organization (DMO) to develop their service level and correct marketing policy that would create destination appeals for inbound and domestic meetings in Thailand. Cró \& Martins, (2017) stated that as competition in the MICE sector grows, it is critical for destinations and facilities to identify key destination factors, influence association's site selection decisions and to develop marketing strategies based on those identified factors (Go and Govers, 1999:40).

\section{Literature Review}

\subsection{Inbound and domestic meetings: the differences between corporate and association meetings}

Medical, scientific, and other academic meetings, as well as trade organizations, professional body and social grouping meetings are being segmented by the ICCA or International Convention \& Congress Association. Meetings \& Conventions are difference in nature. Rockett and Smillie (1994) defined 'Meetings' or corporate meetings as rather compulsory to attend at off-site gatherings of corporations or associations, whereas conventions or association meetings are open to the entire membership of the association (Cró and Martins 2018). According to Oppermann (1996) and Weber (2001), associations are claimed to be relatively 


\section{$4^{\text {th }}$ International Conference on BUSINESS, MANAGEMENT \& ECONOMICS}

15 - 17 DECEMBER 2020

BERLIN, GERMANY

flexible when choosing a meeting destination while the corporate sector, business locations and headquarters are claimed to be selective in choosing their meeting destination. In a contrary, there is a growing interest among corporate organizations to hold their meetings in a less conventional or novel setting. (Callan \& Hoyes, 2000; Leask \& Hood, 2001) Unusual venues or second-tier destinations are preferred (Ariffin, Ahmad et al. 2008). Ariffin, Ahmad et al. 2008 study finding the segmentation of meeting by geographic location and behavioral segmentation of benefits sought. The latter group is divided into two-dimensional values of "utilitarian/non-utilitarian". The market will then serve two large segments: novelty-seekers and novelty-avoiders. Novelty seekers are high in novelty preference and associated with the novel destination.

Toh et al. (2007) developed 11 important differences between corporate meetings and association meetings as summarized in Table 1. The author adds an additional aspect when considering the local demand in Thailand. This contains primary data taken during interviews with 12 experts from the demand side.

Table 1: Differences between corporate meetings and association meetings adapted from Toh et al. (2007)

\begin{tabular}{|c|c|c|}
\hline Differences & Corporate meetings & Association meetings \\
\hline Objective of meetings & $\begin{array}{l}\text { - Costs must be minimized within } \\
\text { reason } \\
\text { - Sharing business goals, targets, } \\
\text { and unity }\end{array}$ & $\begin{array}{l}\text { - } \quad \text { Revenue generating opportunity } \\
\text { - } \quad \text { Knowledge sharing } \\
\text { - } \quad \text { Legacy to the destination }\end{array}$ \\
\hline Type of organization & Corporate employees & Association members \\
\hline $\begin{array}{l}\text { Decision making for site } \\
\text { selection }\end{array}$ & $C E O$, management & Association Committee \\
\hline Nature of meetings & Formal and business like & Informal and family oriented \\
\hline Evaluation & Base on cost saving & $\begin{array}{ll}\text { - } & \text { Success of the conference } \\
\text { - } & \text { number of delegates }\end{array}$ \\
\hline Outsourcing & More outsourcing to independents & $\begin{array}{l}\text { Less outsourcing to association } \\
\text { management companies }\end{array}$ \\
\hline Attrition & $\begin{array}{l}\text { Less concerned as costs absorbed by } \\
\text { corporation }\end{array}$ & $\begin{array}{l}\text { More concerned on unexpected } \\
\text { charges }\end{array}$ \\
\hline $\begin{array}{l}\text { Booking outside the room } \\
\text { block }\end{array}$ & $\begin{array}{l}\text { Less problem due to controllable } \\
\text { number of employees }\end{array}$ & $\begin{array}{l}\text { Cannot control number of } \\
\text { conventioneers }\end{array}$ \\
\hline $\begin{array}{l}\text { Hot dates and pop-up } \\
\text { meetings }\end{array}$ & $\begin{array}{l}\text { Short lead time, frequently chance on } \\
\text { pop-up meetings }\end{array}$ & $\begin{array}{l}\text { Longer lead time, less frequent pop-up } \\
\text { meetings }\end{array}$ \\
\hline Cost reduction & Reduce meeting costs & Reduce conference fees \\
\hline Perks & Less likely to accept & More likely to accept \\
\hline Hotel Choice & $\begin{array}{l}\text { Choose base on basis of facilities, } \\
\text { services, and costs }\end{array}$ & $\begin{array}{l}\text { May choose not to use non-union } \\
\text { hotels even at the higher cost }\end{array}$ \\
\hline $\begin{array}{l}\text { Use of technology in } \\
\text { planning meetings }\end{array}$ & Widespread use of technology & Limited use of technology \\
\hline $\begin{array}{l}\text { Novelty in choosing } 2^{\text {nd }} \\
\text { tier destination }\end{array}$ & $\begin{array}{l}\text { More open to try new destination with } \\
\text { good content and story }\end{array}$ & Less likely due to number of delegates \\
\hline
\end{tabular}

\subsection{Meeting planner's site selection attributes}

Acknowledging the differences between corporate and association meetings, the destination needs to develop resources and facilities to create different attributes that determine a competitive market position (Crouch and Louviere, 2004). Because of this, there are many 


\section{BUSINESS, MANAGEMENT \& ECONOMICS}

\section{5 - 17 DECEMBER 2020}

BERLIN, GERMANY

research studies on destination attributes in order to create the value being offered, reflecting an understanding of meeting planner's decision process and criteria which will perhaps increase the chance to host the event (Vanja Dragicevic et al., 2012). Oppermann (1996) ranks the importance of destination attributes from 126 survey results, obtained from 600 meeting planners, the meeting rooms, and facilities. Top of the list and most important is the hotel service quality. Secondly, they consider availability of hotel room, location attractiveness, safety/security, and ease of transportation. Surprisingly, the climate and night life are put in least important. Cró and Martins (2018) conducts empirical research utilizing regression analysis used by ordinary least squares for the number of association meetings organized in 2014 from the ICCA database. Among the attributes analyzed, the natural and cultural resources, price competitiveness and quality of human resources are the attributes that have a greater impact on the number of meetings organized.

Crouch and Ritchie's (1997) identified taxonomy of site selection from the event host's point of view into 8 categories and 44 dimensions (see table 2).

Table 2: Destination site selection criteria by Crouch and Ritchie's (1997)

\begin{tabular}{|c|c|c|}
\hline Category & Dimension & Indication \\
\hline \multirow[t]{6}{*}{ Accessibility } & Cost & the expenses of transportation and access, cost of attending the convention \\
\hline & Time & the duration/distance of travel and the opportunity cost of that time \\
\hline & Frequency & frequency of connections to the site \\
\hline & \multirow[t]{2}{*}{ Convenience } & the scheduling convenience of the connections, easy access to destination \\
\hline & & availability of air service and convenience of local transportation \\
\hline & Barriers & any travel formalities which inhibit travel such as visas, customs, language \\
\hline \multirow[t]{4}{*}{ Local support } & Local chapter & assistance and backing offered by the local chapter of the association \\
\hline & CVB/Convention center & the extent of planning, logistical and promotional support offered \\
\hline & Subsidies & destination offers to defray costs through rebates and subsidies \\
\hline & $\begin{array}{l}\text { Professional \& human } \\
\text { resource }\end{array}$ & quality of industry personnel and efficiency of industry personnel \\
\hline \multirow{7}{*}{$\begin{array}{l}\text { Extra- } \\
\text { conference } \\
\text { opportunities }\end{array}$} & Entertainment & restaurants, bars, theatres, nightclubs, etc. \\
\hline & Shopping & malls major department stores, low prices etc. \\
\hline & Sightseeing & architecture, cultural attractions, parks, historical sites, local tours, etc. \\
\hline & Recreation & sports and activities either as spectator or participant \\
\hline & Professional opportunities & visiting local clients, negotiations, business deals, networking \\
\hline & Quality of attractions & the perception of the standards of service \& reputation \\
\hline & Safety standard of attraction & the attraction provides a safe and secure environment \\
\hline \multirow{7}{*}{$\begin{array}{l}\text { Accommodation } \\
\text { facilities }\end{array}$} & Capacity & the number of rooms available \\
\hline & Cost & the cost of suitable accommodation at the site \\
\hline & Service & the perception of the standards of service \\
\hline & Security \& safety & the extent to which the hotels provide a safe and secure environment \\
\hline & Availability & are the facilities available when required \\
\hline & Location & accessible and convenience to travel \\
\hline & Food \& beverage & quality and service of $F \& B$ \\
\hline \multirow{3}{*}{$\begin{array}{l}\text { Meeting } \\
\text { facilities }\end{array}$} & Capacity & ability of site to provide suitable sized facilities \\
\hline & Layout & suitability of the facility layout and floor plan/Flexibility \\
\hline & Cost & the cost of the meeting space required \\
\hline
\end{tabular}




\begin{tabular}{|l|l|l|}
\hline \multirow{5}{*}{ Information } & Service & the perception of the standards of service \& reputation \\
\cline { 2 - 3 } & Security \& safety & the extent of which the facility provides a safe and secure meeting space \\
\cline { 2 - 3 } & Availability & are the facilities available when required \\
\cline { 2 - 3 } environment & Food \& beverage & quality up to standard, variety of food, cost of food \& beverage \\
\cline { 2 - 3 } & Experience & has the site performed satisfactorily in the past \\
\cline { 2 - 3 } & Marketing & what is the reputation of the destination among other meeting planners \\
\cline { 2 - 3 } & Climate & the effectiveness of the destination's marketing activities \\
\cline { 2 - 3 } & Setting & the desirability of the destination's climate \\
\cline { 2 - 3 } & Hospitality & the attractiveness of the destination surroundings \\
\cline { 2 - 3 } & Health \& safety & the suitability and standard of local infrastructure \\
\cline { 2 - 3 } & Innovativeness & the extent to which the host organizations excel in welcoming visitors \\
\cline { 2 - 3 } & Functionalization & destination innovativeness \\
\hline Other criteria & Risks & ability of facilities to combine convention and entertainment attributes \\
\cline { 2 - 3 } & Profitability & the possibility of strikes and other possible adverse events \\
\cline { 2 - 3 } & Association promotion & Chances of site would produce a profit (loss) for the convention \\
\cline { 2 - 3 } & Novelty & would the site add credibility to association and build membership \\
\hline
\end{tabular}

\subsection{Destination competitiveness; hard \& soft, tangible \& intangible factors}

Armenski, Dwyer, \& Paylukovic, 2018; Hall \& Campos, 2014; Mei, Arcodia, \& Ruhanen, 2015 , state that there are limited studies on natural and cultural destination attractiveness. Instead, more focus on the attributes of destination management where roles of the public and private sectors are favored in supporting destination attractiveness. Being host of International meetings, local communities can benefit from additional income distribution, urban development, and development of destination cities for tourism. (Dwyer, Dragicevic, Armenski, Mihalic, \& Cvlbar, 2016; Nunkoo, 2015). The General Model of Destination Competitiveness by Ritchie \& Crouch (2000) reiterates on the destination management factors. Those of which that 'can enhance the appeal of the core resources and attractors, strengthen the quality and effectiveness of the supporting factors and resources, thus adapting best to the constraints imposed by the [situational conditions]' (Crouch \& Ritchie, 1999: 149). The category includes the activities of destination management organizations, destination marketing management, destination policy, planning and development, human resource development and environmental management (Dwyer and Kim 2003). By nature, the basic criteria for an International meeting site selection focuses on venue and accommodation facilities. Liyanage, Hui, \& Zheng's (2010) study factors influencing satisfaction of the customer through facility management which focuses on facility service and management. Facility service includes the quality of facility staff, while facility management includes general overall management of venues and facilities. In addition, Saeidi, Sofian, Saeidi, Saeidi, and Saaeidi (2015) found the significant relationship of customer satisfaction, organization reputation and competitive advantage as a variable factor to business sustainability. This can be explained that the correct facility management in a destination can influence a destinations competitive advantage that leads to destination performance (Mayuree and Kaedsiri THE LIBERAL ARTS JOURNAL, 2018). Destination appeals are claimed to be important factors for the development of destination competitiveness (Adeyinka-Ojo and Nair, 2015; Ritchie and Crouch, 2003; Zeinali and Jarpour, 2015). Baker, 2007; Pride, 2008 studied on the hard and soft factor attractions while Adeyinka-Oji and Nair, 2015 studied on the hard and soft factor 


\section{$4^{\text {th }}$ International Conference on BUSINESS, MANAGEMENT \& ECONOMICS}

15 - 17 DECEMBER 2020

BERLIN, GERMANY

appeals. Similarly linked to Lamb et al., 2004; Wadawi et al., 2001) who stated that a product can be referred to as tangible or intangible services. Pride (2008) and Ritchie and Crouch (2003) have proposed that the infrastructure, accommodation amenities and tourism facilities are the hard factors and attractions that aid in providing memorable experiences to tourists. Ancincova, 2014; Dwyer and Kim, 2003 stated that the soft factors are referred to as the visitors' perception or experiences while experiencing the tourism activities as provided by the tourist destination.

\section{Research Methodology}

The objectives of this research are to analyze the site selection attributes that attract destination selection processes from a demand perspective. Twelve experts ranging from meeting planners who focus on corporate meetings, equivalent to destination management companies (DMCs) to association meeting planners, commonly known as professional convention organizer's (PCOs) will be studied in three phases.

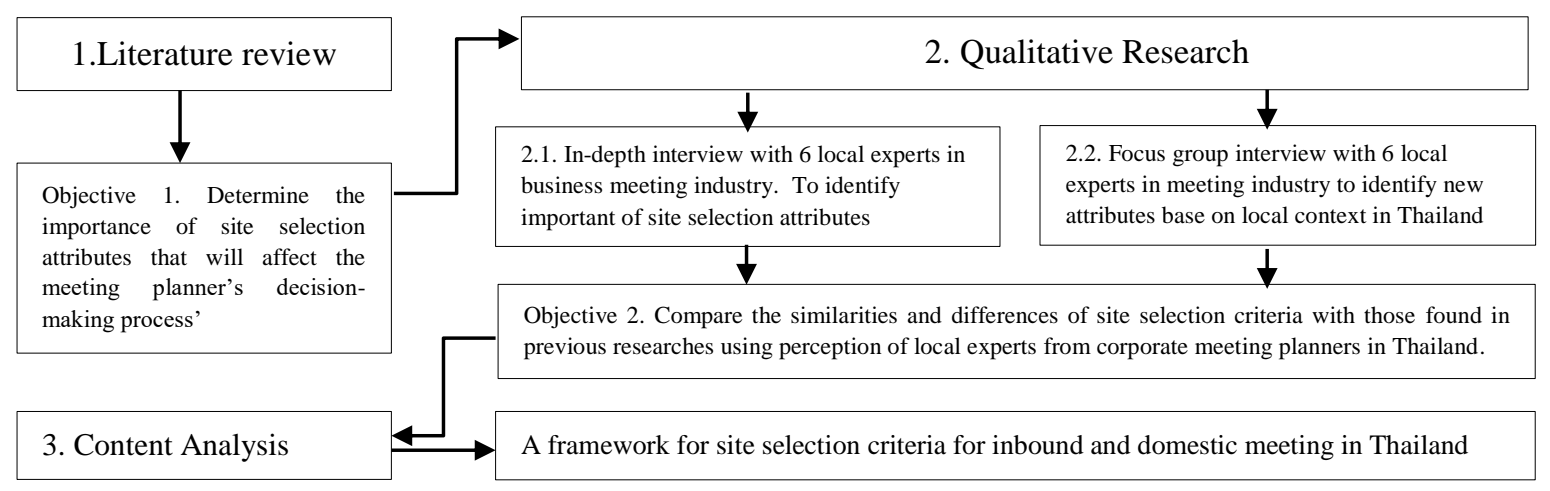

Firstly, the systematic review of previous research on the attributes and processes of site selection for International meetings have been extensively reviewed. This is to achieve research objective of 'Determine the importance of site selection attributes that will affect the meeting planner's decision-making process'. Secondly, the two qualitative research methods, namely in-depth interviews \& focus group interviews are used to 'Compare the similarities and differences of site selection criteria with those found in previous researches using perception of local experts from corporate meeting planners in Thailand'. Lastly, content analysis from 8 major attributes will be analyzed and the validity and weighing of the destination selection attribute will be empirically confirmed. This part will suggest a research framework for further development in the next phase for meeting destination selection criteria of inbound and domestic MICE.

\subsection{Qualitative research}

A series of qualitative research methods such as in-depth interviews and focus group interviews were conducted sequentially to analyze the site selection attributes which may not yet have been mentioned in earlier studies. From a thorough literature review, the most known of Crouch \& Ritchie's (1997) taxonomy of site selection attributes are based on the extensive 
review of 64 academic and trade publications. These will be used to argue for the similarity and differences in the Thai context. To achieve the objectives of the research, an in-depth interview was conducted as a research tool to explore and better understand the attributes that trigger meeting planner's decision making when choosing the site for their events. The respondents were six professional convention organizers, five of them are engaged in organizing International conventions and one focusing on local convention. All respondents have over 10 years of extensive industry experience and represent the Thailand Incentive \& Convention Association. The semi-structured in-depth interview consists of three parts, including the demographic and professional details, as well as the respondent's perspective about the site selection attributes. The respondents were asked to rate the importance of each attribute using 7 -Likert scale to empirically analyze likeness and differences from expert views. Finally, a focus group interview was conducted with 6 experts (4 Destination Management Companies, 1 Professional Convention Organizer and 1 meeting planner. All the respondents have over 10 years' experience in organizing International corporate meetings in Thailand. The scale of the meetings varies from 200 to 20,000 delegates. Some of them used to be engaged in a bidding process to get corporates and multi-national companies to have their meeting in Thailand numerous times. All of them represent the Society for Incentive Travel Excellence or SITE Thailand. The main reason to use a focus group is to find common attributes which are considered and discussed amongst the group based on their working experience. Currently there are limited studies on corporate meeting planners in comparison to convention meeting planners ${ }^{1}$.

Focus groups were instructed to gain insights of corporate meeting selection attributes affecting International corporation decision making. The session lasted 2.5 hours and was casually conducted by researchers who acted as a moderator panel. The questions were semistructured starting from the professional background and working experience of the respondents. After, questions regarding perception of the importance given to each destination attribute in the process of selecting a meeting destination were asked to all participants. While the respondents discussed and exchanged their experience, the moderator observed and took record. As suggested by Byers and Wilcox (1991), the findings of a focus group interview should be coded using the classifications of $\mathrm{C}$ (consensus), and $\mathrm{A}$ (areas of agreement/disagreement)(Jo, Park et al. 2019).

\section{Results}

\subsection{In-depth interviews}

The researcher analyzes the recent study by Crouch and Ritchie (1997) who classify the multitude of site attributes into eight categories: 1) Accessibility 2) local support 3) additional conference opportunities 4) accommodation facilities 5) meeting facilities 6) information 7) site environment and 8) other criteria. These attributes have been tested using an in-depth interview and a focus group discussion method with Thailand's leading meeting planners and professional convention organizers. The results have been inconsistent with Crouch and Ritchie; however, the important of all attributes are being interpreted differently by author in

${ }^{1}$ Corporate meetings are compulsory off-site gathering of corporations or associations which company sponsored for the expense of the delegate, while conventions or association meetings are open to membership of the association (Cro' and artins 2018) 
three dimensions. Tangible attributes: namely, accessibility, additional conference opportunities, meeting/accommodation facilities and local support together with Intangible attributes like destination information, site environment and other criteria are treated as 'Basic criteria' to exclude certain destination or sites for convention. The reason is that conventions pertain a sizable group of delegates from 50 up to 3,000. In conclusion, easy access and the $\mathrm{min} / \mathrm{max}$ capacity of the venue will be prioritized, followed by budget so that organizing the event will be cost effective. To orchestrate the destination offers successfully, local DMC acts as a 'moderator' in creating the right match between event host's business objectives and destination attributes. Additional 15 attributes derived from in-depth interview analysis, need mediator to put together all the jigsaw pieces (Jo, Park et al, 2019).

Results from an in-depth interview in comparison with existing literatures can be identified as followed:

A. Important factors: Scores have been classified into High (range of 5.1-7.0), Medium (3.15.0), and Low (1.0-3.0) using scaling calculation as follow:

$$
\text { Range }=\text { Maximum }- \text { Minimum/Interval }
$$

B. Out of 8 major attributes, accommodation facilities obtained the highest ranking with 5.87 out of 7. Accessibilities scored 5.66 and Extra-Conference Opportunities scored 5.2. While the least important factors; namely, Destination Information 4.85, Local support 4.87 and other criteria 4.90 were placed into the medium bracket.

C. The findings indicate "high range" of 25 attributes with scores higher than 5.1 and "medium range" of 19 attributes with scores between 3.1-5.0. None of the attributes received a score below 3.1. Thus, it can be concluded that site selection criteria for inbound and domestic from Thai local experts are in line with previous literature findings.

D. New factors: from in-depth interviews and analysis, there are repeating attributes being mentioned by the respondents. To find a significant relationship, the focus group then conducted to find the consensus and agreement of these 17 new dimensional attributes.

Table 3: Site selection attributes for inbound and domestic meeting from local experts in Thailand

\begin{tabular}{|l|l|c|c|c|c|c|}
\hline \multirow{4}{*}{ Attributes } & \multicolumn{2}{|c|}{ Dimension } & \multicolumn{2}{c|}{$\begin{array}{c}\text { Finding from In- } \\
\text { depth interviews }\end{array}$} & \multicolumn{2}{c|}{ Attributes from Focus group } \\
\cline { 3 - 7 } & & Score & Range & $\begin{array}{c}\text { New } \\
\text { attribute }\end{array}$ & $\begin{array}{c}\text { Consensus } \\
(\mathbf{1 0 0})\end{array}$ & $\begin{array}{c}\text { Agreement } \\
(\mathbf{5 0} \%)\end{array}$ \\
\hline \multirow{4}{*}{$\begin{array}{l}\text { D. Accommodation } \\
\text { facilities }\end{array}$} & D1. Capacity & 6.2 & High & & & \\
\cline { 2 - 7 } & D4. Security \& safety & 6.1 & High & & & \\
\cline { 2 - 7 }$($ Average 5.87) & D6cation & 6.0 & High & & & \\
\cline { 2 - 7 } & D3. Service & 5.9 & High & & & \\
\cline { 2 - 7 } & D2. Cost & 5.8 & High & & & \\
\cline { 2 - 7 } & D5. Availability & 5.8 & High & & & \\
\cline { 2 - 7 } & D7. Food \& Beverage & 5.3 & High & & & \\
\hline A. Accessibility & A4. Convenience & 6.2 & High & & & \\
\hline
\end{tabular}




\begin{tabular}{|c|c|c|c|c|c|c|}
\hline \multirow{4}{*}{ (Average 5.66) } & A1. Cost & 6.0 & High & & & \\
\hline & A2. Duration/distance & 5.5 & High & & & \\
\hline & A3. Frequency of connections to site & 5.4 & High & & & \\
\hline & A5. Barriers such as distance, logistics & 5.2 & High & & & \\
\hline \multirow{5}{*}{$\begin{array}{l}\text { C. Extra- } \\
\text { conference } \\
\text { opportunities }\end{array}$} & C7. Safety standard of attraction & 6.1 & High & & & \\
\hline & C5. Professional opportunities & 5.8 & High & & & \\
\hline & Networking with local contact & & & $\checkmark$ & & $\checkmark$ \\
\hline & C6. Quality of attractions & 5.3 & High & & & \\
\hline & C1. Entertainment & 5.2 & High & & & \\
\hline \multirow{3}{*}{ (Average 5.20) } & C3. Sightseeing & 5.1 & High & & & \\
\hline & C2. Shopping & 4.6 & Medium & & & \\
\hline & C4. Recreation & 4.3 & Medium & & & \\
\hline \multirow{7}{*}{$\begin{array}{l}\text { E. Meeting } \\
\text { facilities }\end{array}$} & E5. Security \& safety & 5.8 & High & & & \\
\hline & E1. Capacity & 5.7 & High & & & \\
\hline & E4. Service & 5.3 & High & & & \\
\hline & E2. Layout & 5.2 & High & & & \\
\hline & E3. Cost & 5.2 & High & & & \\
\hline & E6. Availability & 5.1 & High & & & \\
\hline & E7. Food \& Beverage & 4.1 & Medium & & & \\
\hline \multirow{9}{*}{$\begin{array}{l}\text { G. Site } \\
\text { environment } \\
\text { (Average 4.92) }\end{array}$} & G5. Health \& safety & 6.2 & High & & & \\
\hline & G2. Setting & 5.8 & High & & & \\
\hline & G3. Infrastructure & 5.6 & High & & & \\
\hline & G1. Climate & 5.5 & High & & & \\
\hline & Seasonal/timing & & & $\checkmark$ & & $\checkmark$ \\
\hline & G4. Hospitality & 5.1 & High & & & \\
\hline & Support from local community & & & $\checkmark$ & $\checkmark$ & \\
\hline & G6. Innovation & 4.4 & Medium & & & \\
\hline & G7. Functionalization & 4.0 & Medium & & & \\
\hline \multirow{7}{*}{$\begin{array}{l}\text { H. Other criteria } \\
\text { (Average } 4.90)\end{array}$} & H1. Risks & 5.7 & High & & & \\
\hline & H3. Association promotion & 5.0 & Medium & & & \\
\hline & Expanding Membership & & & $\checkmark$ & $\checkmark$ & \\
\hline & H2. Profitability & 4.7 & Medium & & & \\
\hline & Business objective: time/budget & & & $\checkmark$ & $\checkmark$ & \\
\hline & H4. Novelty location & 4.2 & Medium & & & \\
\hline & Experience: novelty destination & & & $\checkmark$ & & $\checkmark$ \\
\hline \multirow{11}{*}{$\begin{array}{l}\text { B. Local Support } \\
\text { (Average 4.87) }\end{array}$} & B1. Local chapter & 5.4 & High & & & \\
\hline & Lobbyist in the association committee & & & $\checkmark$ & & $\checkmark$ \\
\hline & B4. Professional \& Human resource & 5.7 & High & & & \\
\hline & Local staff team and service & & & $\checkmark$ & $\checkmark$ & \\
\hline & Local community \& influencers & & & $\checkmark$ & $\checkmark$ & \\
\hline & Local support: welcoming gesture & & & $\checkmark$ & $\checkmark$ & \\
\hline & Willingness or determination & & & $\checkmark$ & $\checkmark$ & \\
\hline & Local DMC \& Planner & & & $\checkmark$ & $\checkmark$ & \\
\hline & Local meeting partners: experienced & & & $\checkmark$ & $\checkmark$ & \\
\hline & B2. CVB/Convention center & 4.7 & Medium & & & \\
\hline & B3. Subsidies \& government incentive & 4.2 & Medium & & & \\
\hline \multirow{6}{*}{$\begin{array}{l}\text { F. Information } \\
\text { (Average 4.85) }\end{array}$} & F1. Experience of destination & 5.4 & High & & & \\
\hline & F3. Destination marketing & 4.9 & Medium & & & \\
\hline & Customer profile \& requirement & & & & & \\
\hline & Up to date information & & & $\checkmark$ & $\checkmark$ & \\
\hline & Destination information/facilitation & & & $\checkmark$ & $\checkmark$ & \\
\hline & F2. Reputation (image) & 4.8 & Medium & & & \\
\hline
\end{tabular}




\section{BUSINESS, MANAGEMENT \& ECONOMICS}

\section{Source: author}

Credential of meeting planner

\subsection{Focus group interview}

To analyze the impact of each attributes, two focus groups have been scrutinized. Firstly, a focus group covered the top view of CVB in Thailand to explore how a governing body put their priority and importance to which attributes. The second group analysis was conducted after an in-depth interview to test the degree of importance from group consensus, agreement/disagreement, and individual comments. The result of the $2^{\text {nd }}$ focus group was listed from additional attributes not yet or rarely identified in the previous research and is listed as follows:

A. There are 17 new attributes from the focus group which have been defined by 8 major attributes; Local support (7 attributes), Destination information (4 attributes), Other criteria (3 attributes), Site environment (2 attributes) and Additional Conference opportunities (1 attribute).

B. Each attribute is classified into 'Consensus', being the attribute that all respondents have mentioned and 'Agreement', being the attribute that is mentioned in over $50 \%$ of respondents.

C. There are no additional attributes for accessibilities, accommodation facilities and meeting facilitate in any dimension. This indicates that most aspects are well covered and are regarded as common factors or 'basic criteria' that can be universally applied in site selection process.

\section{Conclusion \& Implication}

\subsection{Theoretical implications}

The findings of 61 attributes where 44 are from previous literature and 17 are from qualitative research. The attributes are classified into three dimensions made up of; Basic criteria, Value added and Business objectives (see figure 1). The result from in-depth interviews with 44 factors from the previous research showed the alignment with a Thai meeting planner's perspective. The three highest ranking attributes with a score above 5.1 out of 7 are Accommodation facilities, accessibilities, and meeting facilities. The respondent emphasizes that these top 3 attributes are of a basic criterion to consider whether the destination is good to proceed further. Meetings by nature can cater for large groups of delegates, with responsibility on the meeting planners to offer suitable venues and facilities that provide confidence that the event will be a success. Interestingly, in the second layer of 'value added', local support and destination information which

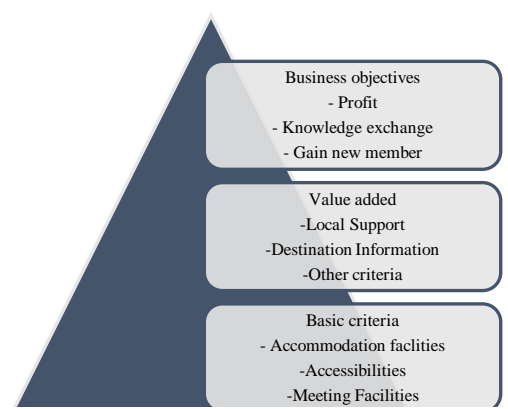

Figure 1: 3-dimensional site selection criteria 
ranked as less of a priority from in-depth interviews were found to be important findings from the focus group. There are 7 new attributes which fall under local support, these are; Local staff teams and services, local communities \& influencers, local support in welcoming gestures from local communities, willingness/determination to establish a legacy to destination, local DMC's (Destination Management Companies) /Planners, along with local meeting planner's experience and credibility. Following on from the above, destination information includes 4 new attributes consisting of; Customer profiling that matches with the type of events, up to date information of the destination, facilitation from the destination, credentials of the meeting planner and local industry. The latter group are illustrating the destination experience in hosting inbound meetings and matching with a planner's perspectives.

\subsection{Practical implications}

The study analyzed important attributes that provide a better understanding to destinations and Convention Bureau regarding the site selection process that will affect a meeting planner's decision-making process. According to Crouch's (2007) research in Modelling Destination Competitiveness and Destination Management leading by DMO, the agency responsible for the integrated city management came in $2^{\text {nd }}$ rank by factors of importance. DMO has the primary function of fostering local events by linking optimum demand with supply for optimal resource utilization (Leiper's model, 1979, Pike, 2008). Furthermore, the Encyclopedia of Tourism, Anderson, (2000) further explained that these agencies include the Convention \& Visitor Bureau (CVB), as well as the tourism promotion organizations, provincial or regional tourism bureau who's responsible for coordinating and building networks with relevant business partners. To attract and bid for MICE events, emphasis on the development of human resource, service quality and destination marketing promotion should be considered. (Lorn Sheehan et al, 2015). Hassan (2000) mentioned that destination competitiveness can be achieved with destination management that focuses on a unique comparative advantage using careful analysis and response to the core values and requirements of the segmented marketplace'(Hassan, 2000: 240). Additionally, Cro'\& Martins (2018) resonance that to host International meetings successfully, convention \& visitor bureaus and destination management organization (DMOs) should be active. Diverse processes of developing and marketing effective strategy should be applied to attract more participants.

\subsection{Future research}

Interviews are limited to meeting planners who are in Bangkok and major cities. Having more diverse groups in other provinces, would have meant that the study could further explore the empirical data highlighting the importance of intangible attributes such as local support in creating a destination competitiveness in Thailand. This finding helps develop a framework for domestic site selection attributes that would enable such organizations as Convention \& Visitor Bureau (CVB), Cities and Destination Management Organization (DMO). Developing their service level and the right marketing policies would create destination appeal and attract inbound and domestic meetings to destinations in Thailand. Since the finding clearly states the dimension of attributes in which to attract International meetings, the attributes do not simply focus on certain hardware or software. The success of an event starts from the business objective of a host organizer who also serves their delegates and business bottom line. The meeting planner takes the requirement and expands an idea with basic criteria and scales down the choices. This is considered 'demand push' to wherever destination that might fit in. 
Alternatively, if a destination were to itself, correct hardware such as destination facility, accessibility and capability must be in line with software which includes Professional service, hospitality, destination image and marketing, etc. And finally, if the meeting planner catches the idea and uses their expertise to manage all attributes plus create story telling base on destination DNA, that's how the proper planning of a bidding proposal would effectively create the 'destination pull'. To conclude, the development of destination assessment tools to evaluate basic criteria, then recommend with options of destination based on value added and business objectives. Using this might suggest the way CVB and destination marketing can be successfully positioned. Once complete, the destination can create a destination brand DNA and branding in collaboration with their community to create a destination which appeals for each type of International meeting successfully.

\section{Acknowledgement}

This paper may have not been completed without the support from my advisors and co-advisor, and I would like to extend my deepest appreciation for their contribution extensively. I would like to also thanks to my beloving colleagues who give support and sharing best practice without hesitation, and I appreciate the friendship as much as the academic fulfillment. A special thanks to my family for mentally support and considerate understanding on the time and effort that I have put together to accomplish this work. I anticipate that this piece of work will shed the light for Thailand Convention \& Exhibition Bureau, destinations, accommodations, and meeting facilities, to create the strategy that are suitable with the site selection attributes for domestic meeting. Considering the recent pandemic Covid19 that restricted international delegate to the country, domestic meeting might as well be the low hanging fruit to capture to keep the business continuity.

\section{References}

Ariffin, A. A. M., et al. (2008). "Corporate Meeting Destination Choice: The Influences of Consumption Value, Organizational Structure and Personality." International Journal of Hospitality \& Tourism Administration 9(4): 313-326.

Cró, S. and A. M. J. J. o. V. M. Martins (2018). "International association meetings: Importance

of destination attributes." 24(3): 218-233.

Deokhyun Jo, Hyo-Yeun Park, Yeongbae Choe, Dae-Kwan Kim (2019). Destiantion-selection attributes for international association meetings: A mixed-methods study, Journal of Destination Marketing \& Management 13 (2019) 61-72.

Dwyer, L. and C. Kim (2003). "Destination Competitiveness: Determinants and Indicators." Current Issues in Tourism 6(5): 369-414.

Events Industry Council (2009). The Economic Significance of Meetings to the US Economy, PCMA Education Foundation, www.pcma.org February 21, 2018

Iwamoto, H., et al. (2018). International Convention Destination: Researchers' Preferences and

Requirements. 7th International Congress on Advanced Applied Informatics. 


\section{$4^{\text {th }}$ International Conference on BUSINESS, MANAGEMENT \& ECONOMICS}

15 - 17 DECEMBER 2020

BERLIN, GERMANY

Jo, D., et al. (2019). "Destination-selection attributes for international association meetings: A mixed-methods study." 13: 61-72.

Mayuree \& Kaedsiri (2018). "Conceptual Sustainable Facility Management in MICE Venue Influencing Competitive Advantage and Firm Performance." The Liberal Arts Journals.

Rex S. Toh, Dean Perterson and T. Noble Foster (2007). Contrasting Approaches of Corporate and Association Meeting Planners: How the Hospitality Industry Should Approach Them Differently, International Journal of Tourism Research

Stanley Nwobodo (2016). Factors that influence destination selection for business events in Malaysia, thesis submission for Swinburne University of Technology

Seyhmus Baloglu, Curtis Love (2005). Association meeting planners' perceptions and intentions for five major US convention cicties: the structured and unstructured images, Tourism Management 26 (2005) 743-752

PCMA Convene (May 2020). Covid 19 Recovery Dashboard survey dated May 18-21. Professional Convention Management Association (PCMA), www.pcma.org

Research unit, Thailand Convention \& Exhibition Bureau (2020). Covid 19 monthly report August 2020

Thailand Management Association (2019). Whitepaper on "Enhancing MICE industry through innovation 2019"

Yang Huo (2014). Meeting Planners' Perception on Convetion Destination Attributes: Empirical

Evidence from Six Major Asian Convention Cities. The Journal of Business Inquiry 2014, 13, Issue 2, 70-80. 